\title{
SUSTAINABLE TOURISM ON THE POLE OF COLD
}

\author{
Liudmila Zamorshchikova ${ }^{1}$ \\ Irena Khokholova ${ }^{2}$
}

DOI: https://doi.org/10.31410/ERAZ.2019.147

\begin{abstract}
Today two geographical points in Yakutia consider themselves the Poles of cold: Oymyakon and Verkhoyansk. The policy of promoting Oymyakon and Verkhoyansk as tourist sites associated with the Poles of cold is varied according to the specific socio-economic and cultural conditions. If Oymyakon is more promoted as the Pole of cold on the scale of international and regional tourism thanks to its infrastructure, Verkhoyansk keeps the reputation of the sacred place for the local population, but also of the place for scientific tourism and research. The cross-sector partnerships can be seen as powerful mechanisms for building constructive relationships between tourist companies and local communities and contributing to sustainable community development. The engagement of indigenous communities and their participation in all stages of the tourism development (concept, promotion and realisation of tourist products) contribute to achieve a more sustainable development of tourism in situ. In order to study the history and different aspects of polar belonging we analyzed a large number of scientific texts, literary, historical documents, legends, folklore, stories and blogs of travelers and tourists, but also the mapped and local toponyms, interview and questionnaires.
\end{abstract}

Keywords: Russian Arctic, pole of cold, indigenous communities, promotion of extreme tourism, social responsibility, environmental and human impact.

\section{INTRODUCTION}

Towadays the interest in the Artic- and North-related topics attracts the attention of many 1 politicians, scholars, researchers, entrepreneurs, and tourists. The Arctic regions of the Russian Federation, the territories of which have an open access to the Northern sea route, are the shorelands of the Arctic Ocean in Yakutia. The Sakha Republic (Yakutia) is one of the largest industrial and national regions of the Russian Far East; its territory is 6 times larger than that of France and 14 times larger than the territory of Great Britain. There are two locations in the Sakha Republic (Yakutia) which can have a high probability of being recognized as an integral part of the Pole of Cole, namely - Verkhoyansk and Oymyakon. The coldest territories are considered to be the ones located near Verkhoyansk and Oymyakon, where the temperatures can decrease down to $-70{ }^{\circ} \mathrm{C}$. The summer (short-term) temperature can reach an average of $+30^{\circ} \mathrm{C}$. Such extreme annual temperature fluctuations (100 degrees) can only be observed in Yakutia. Today, winter tourism in Yakutia is a very attractive form of tourism worldwide. Both poles, especially Oymyakon, owing to its infrastructure, attracts tourists with its uniqueness; hundreds of tourists come to Yakutia from different parts of the world to get a first-hand experience of the extreme cold and severe climate, which represent a special kind of extreme activity.

\footnotetext{
1 M. K. Ammossov North-Eastern Federal University, 58 Belinsky str, Yakutsk, Republic of Sakha (Yakutia), Russia

2 M. K. Ammossov North-Eastern Federal University, 58 Belinsky str, Yakutsk, Republic of Sakha (Yakutia), Russia
} 


\section{GEOGRAPHIC LOCATION OF THE POLES OF COLD}

Verkhoyansk is a town in the Verkhoyansky administrative district of the Sakha Republic (Yakutia), situated on the right bank of the Lena River and $92 \mathrm{~km}$ south-west from the administrative center of this district - the town of Bataguy, the northernmost town of Yakutia. Verkhoyansk is officially registered as the Pole of Cold of the Northern hemisphere. It is one of the northernmost towns located in the circumpolar region and the smallest populated towns of Russia (ranking $3^{\text {rd }}$ from the bottom of the list): only 1,150 reside there. The only way to get there is to, first, travel by plane from Moscow to Yakutsk, then take another local airline plane and fly over the Lena River and the Verkhoyansky range, thus, reaching Bataguy (the administrative center of the Verkhoyansky district), and, finally, drive down a dirt road to Verkhoyansk. There is no airport in Verkhoyansk, it does not operate, to be more precise; it was closed after the fall of the USSR.

Initially, Verkhoyansk was established as a Russian Cossacks settlement, later it became a place for political exiles. On January 15, 1885, one of these exiles, S.F. Kovalik, registered and entered this registry in the meteorological station journal the lowest air temperature of $-67.1^{\circ} \mathrm{C}$. In 1892 , an even lower temperature was registered, amounting to $-67.8^{\circ} \mathrm{C}$. In 2005 , the local administration of the town set up a memorial stand to commemorate the lowest registered temperature in the Northern hemisphere. The region has a sub-Arctic and sharp-continental climate. The average temperature in January ranges from $-38{ }^{\circ} \mathrm{C}$ to $-48{ }^{\circ} \mathrm{C}$, and from $+15{ }^{\circ} \mathrm{C}$ to $+17^{\circ} \mathrm{C}$ in July. The average rainfall level amounts to an annual range of $150 \mathrm{~mm}$ to $300 \mathrm{~mm}$.

Verkhoyansk was founded in 1638 by Posnik Ivanov and was intended to be used as a Cossack winter settlement [1]. Beginning from 1957, the local and the only existing school at that time in Verkhoyansk, began to collect findings on the history of the town. Based on these findings, a local lore museum was created. The exhibition of the museum titled "The Pole of Cold of the Northern Russian hemisphere" has a large range of historical findings connected to the unique aero-hydrometeorological station. The museum is also unique in its displays of Yakut cultural heritage of the Verkhoyansky district. A yurt, which is an ancient dwelling, was set up next to the main museum complex.

The administrative district under study has raw materials deposits, including tin, antimony, gold, silver, tungsten, copper, etc. In the Soviet times, there used to be large excavations of tin near the towns of Bataguy and Ese-Haya, including the Kester deposit, and gold was retrieved in the town of Laso.

The current status of the district makes it an agricultural area. The agricultural sector comprises of meat and dairy production, horse- and reindeer herding, and fur trade.

Oymyakon is another location which can potentially be considered the Pole of Cold of the Northern hemisphere. The village is located below the Polar Circle. It is situated in the mountain hollow, in which, during the nighttime the cold air condensates; this explains its territorial location in the Pole of Cold of the Northern hemisphere, regardless the fact that it has not been recognized as such up to date. The meteorological observations are not held precisely in Oymyakon itself but in the airport with the same name; it is located $40 \mathrm{~km}$ away from the village and $2 \mathrm{~km}$ away from the township of Tomtor. 
Oymyakonsky ulus (region) is situated in the north-eastern part of the Sakha Republic (Yakutia) covering an area of 92.2 sq. $\mathrm{km}$ making it the $14^{\text {th }}$ largest territory of the republic. The Oymyakonsky district shares borders with the Magadan Oblast in the east and with the Khabarovsky Krai in the south, it also can common borders with the Tomponsky district in the west and the Momsky district in the north. The Chersky and the Verkhoyansky mountain ranges run through the territory of this district. These mountain ranges have the highest peak point in the European part of Russia, i.e., the Mus-Haya peak (3,011 m) [2].

The Oymyakonsky district is located in the heart of mountain ranges and peaks. The relief of the area comprises of the following chorographical units, the largest of them being the Oymyakon mountain range situated in the center of the district of the north-east of the Nerskoye low range. The mountain range systems of the district in general make up a natural large-sized basin, called the Oymyakon basin. The main reasons for the formation of extremely low temperatures in the Oymyakon region are seen in the relief: it has isolated valleys, basins and it is at a distant location from the ocean; apart from this, there are circumpolar processes which affect the climate [3].

The Oymyakon district acquired its status as the Pole of Cold due to the extreme low temperatures. In 1924, the Russian scholar and geologist, Sergey Obruchev recorded the lowest temperature in the northern hemisphere, as low as $-71.2^{\circ} \mathrm{C}$. The Oymyakon region has always aroused a lively interest among Russian and international tourists alike [Ibid., 3].

In general, when the two poles are compared, they have an approximately the same average temperature of $-69^{\circ} \mathrm{C}$. "The Oymyakon Station is located in the basin, for this reason, it makes it difficult for the air temperature to change. The reason for the low average monthly temperature decrease in Oymyakon is the radial freezing process and weak inflow of warm air" [4].

The Verkhoyansk station is located approximately $750 \mathrm{~km}$ to the north-west from the Oymyakon station. For this reason, it must be significantly colder in Verkhoyansk compared to Oymyakon (it is considered that the horizontal gradient of the average annual temperature amounts to a few point degrees per $100 \mathrm{~km}$; it might be different for the winter air temperature rates). The difference in the latitude, on the one hand, and the difference in the longitude, on the other hand, is mutually compensated to some extent with regard to the way they affect the air temperature and its minimal rates. The first-hand priority is given to the effects caused by the relief forms [Ibid., 4].

\section{TOURISM IN THE POLES OF COLD}

Local "points of growth" of tourism are concentrated in the places where of unique natural objects and transportation hubs "come into contact", which is especially noticeable in the middle stream of the Lena River, on the coast of the Arctic Ocean, in the mountains of Verkhoyansk.

The Verkhoyansky and Oymyakonsky districts have a potential for the development of tourism, which is not yet fully realized by local communities. Therefore, in conditions of insufficient funds for the development of infrastructure, the natural conditions and resources can allow the development of ecological, cultural, scientific and extreme tourism, sports hunting, fishing and cruises. However, in the last 5 years, tourism in the Pole of Cold, i.e., Oymyakon is gaining its popularity among tourists from different countries. According to V. Obedin, "one of the most popular tourist routes in the republic is the winter rally to Oymyakon within the framework of "the Pole of Cold Festival", not counting summer cruises to Lena Pillars [5]. 
Being he Cold Pole of the northern hemisphere, Oymyakon is covered by tourists much more efficiently than Verkhoyansk: the airport contributes to the rapid achievement of the goal. In the village of Tomtor (where the writer V. Shalamov served the last two years of his exile), a tourist rally is held annually, and in Oymyakon itself the local Santa Clauses gather annually. "Today the "Pole of Cold Festival", and the "Winter begins in Yakutia" festival and many other events are held with the direct participation of Chyskhaan (the Yakut Santa Claus); domestic and foreign travelers strive to get to Oymyakon district to meet with Chyskhaan and experience "frigid" cold" [6].

In the scientific literature and more often in the media, as well as in the discourse of tourist advertising in Yakutia, the natural cultural landscapes of Kisilyakh Verkhoyansk district are mentioned. The Kisilyakh Mountains cover a total area of $121 \mathrm{sq} . \mathrm{km}$ and are one of the most unique and highest peaks of the Verkhoyansk district, containing the remnants of rocks. In the spurs of the Kisilyakhsky ridge, one can meet Kigilyakhs (or rock formations) of various forms, for example, "The Martian", "The Penitent Magdalena", "The Wounded Soldier", "The Gates of Hell", "The Head of the Giant", etc. "Kisilyakh (in Yakut language) is a tall stone pillar, a weathering figure, a rock sticking up on the surface of flat mountains. From a distance, they look like a person or a group of people, for which they are named after the Yakut word kisi - "person". The term is widely used in regional geography, literature in a distorted form of Kigil instead of Kisilyakh-Tas - "man-stone"" [7]. Due to the fact that the local people consider the Kisilyakh mountains to be sacred places, tourist trips to these places are not frequent, although among tourists this direction is in a particular demand. The key factors limiting tourism in the Verkhoyansk district are:

1. Poorly developed infrastructure. Due to the lack of its own revenues in the district budget for a number of years, there was no major overhaul, technical renovation of housing and public utilities facilities, transport, communications, road repair, high wear-off, low comfort, lack of an airport in Verkhoyansk, additional services, lack of professional hotel staff, the discrepancy in the price and quality of the services provided, which resulted in the lack of the prerequisites and incentives for the development of tourism. The instability of the work of life-support facilities, poorly developed communication, transport scheme, inaccessibility of information necessary for entrepreneurs, are factors hindering the development of tourism in the district;

2. The lack of potential knowledge of possible tourism workers and entrepreneurs on the basis of tourism and service, opening and running their own business, business planning, taxation; as a result, there is a low level of local service that does not meet international standards; all these are additional factors hindering the development of tourism in the region;

3. The clear seasonal accessibility of internal transport links.

In addition to the adverse factors hindering the development of the tourism industry in the territory of Verkhoyansk district, there are a number of favorable factors for solving problems related to tourist activities:

1. There is a significant touristic and recreational potential and unique objects of the tourist area;

2. There is a favorable ecological situation and a peaceful social-and-political attitude, as well as tolerance among the local society.

\section{CONCLUSION}

Thus, the existence of two cold poles in the Arctic is still controversial. However, it should be noted that the "Pole of Cold" in itself must bear a certain sense of a sustainable concept, integral and unique in its nature. In this sense, we believe that the proclamation of Verkhoyansk as the "Pole of Cold" had 
a scientific basis and registration. The first observation of a low temperature of - $67^{\circ} \mathrm{C}$ was registered in Verkhoyansk by the researcher S. Kovalik in 1885, that is earlier than in Oymyakon (1924), but with a mark of $-71^{\circ} \mathrm{C}$. The first meteorological station was established in Verkhoyansk, and the city was one of the first to become an outpost of scientific research in the Arctic.

Oymyakon is being visited by tourists much more efficiently than Verkhoyansk, since the airport contributes to the rapid achievement of the goal in the summer, and in the winter the tourists use the Kolyma route. In terms of infrastructure, Verkhoyansk seems to be difficult to reach, in order to reach this destination, it is necessary to fly to the airport of Bataguy, and then go there by a heavy dirt road.

The strategy of sustainable tourism on the poles of cold should be based on understanding the cryosphere as an active element of the universe, as a resource, a source of opportunities for mankind, but not as a source of a threat. The cold constitutes a specific habitat which makes an impact on all spheres of human life.

Such approach to perception of northern territories as an innovative resource of development of a region is quite relevant to the strategy of sustainable development and sustainable tourism of Northern and Arctic territories of Russia.

First of all, tourism development should take into account the fragile sociocultural and ecological system, respect the cultural heritage of local communities, their adaptation experience to severe environment.

\section{REFERENCES}

[1] Sofronov S.: Further east where the Siberian land extends / in http://siberia.ucoz.com/ Chapt06.htm (consulted 08-06-2019).

[2] Izuchenije metereologicheskikh osobennostej Polusa Kholoda (The study of the meteorological characteristics of the Pole of Cold) / in http://www.hintfox.com/article/zychenie-meteorologicheskih-osobennostej-poljusa-holoda.html (consulted 08-06-2019).

[3] Programma socialno-economicheskogo razvitija Munitsipalnogo obrazovanija "Oymakonsky ulus" Respubliki Sakha (Yakoutia) na gody (Program of social-economic development of Oymyakonsky district for years)/ in https://mr-ojmjakonskij.sakha.gov.ru / (consulted 08-06-2019).

[4] Vasilieva T.E.: Polus kholoda Oymyakon I ego nerazgadannyje tajny (The Pole of Cold and its unraveled mysteries, Yakutsk, 2013, 160p.

[5] Obedin V.: Byli vashi - stali nashi! - kak krutyje yakutskije brendy utekajut v chastnyje ruki (Were your - have become ours! - how Yakut brands flow into private hands)/ "Yakutsk vecherny" Newspaper, 10 May 2019.

[6] Romanova L. G.: Chyskhaan ot toponyma k turisticheskomu obrazu (Chyskhaan - from the toponym to the touristic image. // Contemporary problems of the Humanities and Natural Sciences, 2016, No.12-2, p.149-151

[7] Filippova V.V.: Toponimija regionalnykh culturnykh landshaftov (na primere Verkhojanskogo rajona Respubliki Sakha (Yakutia)" (Toponymy of regional cultural landscapes (on the example of the Verkhoyansk region of the Sakha Republic (Yakutia)) Arctic $21^{\text {st }}$ century, 2015, No. 2, pp. 74-85 